ISSN 2078-6441. Вісник Львівського університету. Серія географічна. 2013. Випуск 42. С. 342-349. Visnyk of the Lviv University. Series Geography. 2013. Issue 42. P. 342-349.

504.062.2:630*8 (477:292.452)

“

вло еліш

ввівський н ціон льний університет імені в н вул. . орошенк , 41, 79000, м. ввів, кр їн

осліджено суч сну структуру лісового фонду регіон льного л ндш фтного п рку “ ерхньодністровські ескиди" для под льшого вибору оптим льного режиму використ ння лісових ресурсів. нтенсивне лісокористув ння протягом ст. призвело до нег тивних змін у структурі лісового фонду л ндш фтного п рку. ро н лізов но розподіл лісів п рку 3 к тегоріями 3 хисності т к тегоріями земель, з'ясов но видовий скл д т вікову структуру лісів регіон льних л ндш фтних п рків. изн чено ступінь нтропогенної тр нсформ ції лісів п рку. ля поліпшення суч сної структури лісового фонду з пропонов но оптиміз ційні з ходи, які в рто проводити з ур хув нням функціон льного зонув ння території регіон льного л ндш фтного п рку “ ерхньодністровські ескиди”.

лючові слов : регіон льний л ндш фтний п рк “ ерхньодністровські ескиди”, структур лісового фонду, нтропогенн тр нсформ ція, способи поліпшення.

дним з н йголовніших н прямів природоохоронного лісівництв є визн чення для різних об'єктів природно-з повідного фонду ( ) диференційов ного режиму збереження лісів [4]. озробк режимів збереження лісів є в жливою і для регіон льних л ндш фтних п рків ( $\quad$ ), які ч сто не повною мірою виконують покл дені н них функції.

орг нізовують без вилучення бо ч стково з вилученням земельних ділянок у їхніх вл сників. собливістю цієї к тегорії $€$ те, що їхнє створення м $є$ н меті як охорону і р ціон льне використ ння цінних природних територій, т к і збереження історико-культурних комплексів т об'єктів, здійснення туристичної роботи, з безпечення відпочинку в природі тощо. ме в цій к тегорії зближ ються дві лінії $з$ повідної спр ви - охорон природних л ндш фтів т історико-культурної сп дщини.

великий міжн родний досвід функціонув ння т ких п рків, особливо поширені вони в кр їн х вропи. ндш фтні п рки н йч стіше створюють у регіон льних дміністр тивних одиницях кр їн. прикл д, у трьох прикордонних повіт х ідк рп тського воєводств ольщі функціонують три л ндш фтні п рки: п рк “ еремиське ідгір'я” (61 682 г ), п рк “ лонні гори” (56 032 г ) т п рк “ олин яну” (28 718 г ) [6]. ільшу ч стину території н зв них л ндш фтних п рків з йм ють ліси.

прикордонній зоні кр їни 1997 р. н території сільських р д т рос мбірського р-ну створено “ ерхньодністровські ескиди” (8536 г ). о п рку ввійшли землі лісового фонду держ вного підприємств ( ) “ т рос мбірське лісомисливське господ рство” ( оловецьке лісництво, п ське лісництво, кв. 1-14, 68-75; т р'явське лісництво, кв. 37-58, 64-67) [2].

(C) еліш ., 2013 
ерев жним типом рослинності н території п рку є букові т ялицево-букові ліси й післялісові луки. $\quad$ ліс х зн чну площу з йм ють вторинні смерекові деревост ни, які $€$ біологічно нест більними. території змінен природн віков структур деревост нів. лісовому фонді молодняки з йм ють лише $16 \%$, середньовікові $72 \%$, достиг ючі $-9 \%$. к віков структур є н слідком нер ціон льного ведення лісового господ рств в столітті т потребує оптиміз ції. омун ш мет - н ліз суч сної структури лісового фонду для под льшого вибору оптим льного режиму збереження лісів.

зн чимо, що структур лісового фонду в регіон льних п рк х повинн відповід ти функціон льному зонув нню цих природно-з повідних об'єктів. ж ль, сьогодні всі три ьвівщини не в змозі повною мірою виконув ти покл дені н них функції. оден $з$ цих п рків не м є 3 твердженого функціон льного зонув ння. ише 2005 p.

іністерство екології і природних ресурсів прийняло типове “ оложення про роект орг ніз ції території регіон льного л ндш фтного п рку, охорони, відтворення т рекре ційного використ ння його природних комплексів т об'єктів” [7]. 2007 р. ухв лено рішення про створення дміністр цій . 2011 р. ьвівськ обл сн р д прийнял “ егіон льну прогр му з безпечення діяльності регіон льних л ндш фтних п рків обл сті н 2011-2013 роки" [8].

“ ерхньодністровські ескиди” розт шов ний у меж х р йону ерхньодністерських ескидів в інтерв лі висот від 600 до 1022 м н.р.м. ндш фт п рку, розт шов ного поблизу держ вного кордону, формують три гірські хребти, що перетин ють територію п рку з північного з ходу н південний схід. ерший хребет фіксов ний вершин ми гур (730 м н.р.м.) т безіменною вершиною $з$ ввишки 717 м н.р.м, розт шов ною н північ від с. исовиця. лі $\epsilon$ м сивніший ровий хребет (762 м н.р.м.), продовження якого - г. ичерк (724 м н.р.м.). ретій, н йменший 3 протяжністю хребет формують г. гур - імнянськ $(1022 \mathrm{M})$ т $\quad$ г. молов те $(806$ м) [2]. езв ж ючи н незн чну протяжність (близько 10 км) цей хребет $\epsilon$ н йбільш припіднятою ч стиною п рку. кі природні умови п рку сприятливі для вирощув ння високопродуктивних листяних і хвойних лісів.

долин х, сформов них верхньою ч стиною ністр т його приток ми p. ш нець т р. інинк, розт шов ні сел ерло, олошиново, осохи, оснівк , еликосілля, врів, ш нець, бин, оловецько, розьов т іп’ян . цих бойківських сел х збереглися унік льні дерев'яні церкви: ерло (1847), иців (1931), ш нець (1922), оловецько (1890), н ністрик оловецький (1929) [2]. е свідчить про в гоме зн чення п рку для збереження етнокультурної сп дщини.

о скл ду п рку ввійшли землі лісового фонду “ т рос мбірське ”. ля х р ктеристики лісового фонду використовують різні пок зники, головними з яких $€ з$ г льн і вкрит лісом площ, співвідношення різних к тегорій площ, віков структур , видовий скл д, з п си деревини тощо.

ідповідно до ісового кодексу кр їни, з екологічним і соці льно-економічним зн ченням т з лежно від основних функцій ліси кр їни поділяють н чотири к тегорії з хисності. іси н леж ть до лісів природоохоронного, н укового, історико-культурного призн чення. 2003 р. колектив лісівників підготув в “ етодичні рекоменд ції щодо режиму збереження лісових екосистем н територіях кр їни різних р нгів” [3], які з тверджені спільним н к зом іністерств екології і природних ресурсів кр їни і ерж вного гентств лісового господ рств кр їни. ей документ визн ч є єдині вимоги щодо диференційов ного режиму 
збереження, ефективного використ ння і відтворення лісів н територіях об'єктів у тім числі й у регіон льних л ндш фтних п рк х (т бл. 1). і методичні рекоменд ції потрібно вр ховув ти в держ вному упр влінні т екологічному контролі під ч с пл нув ння природоохоронних т лісогоспод рських з ходів.

блиця 1

истем лісівницьких з ходів н територіях регіон льних л ндш фтних п рків [1]

\begin{tabular}{|c|c|c|c|c|c|c|c|c|c|c|}
\hline \multirow[b]{2}{*}{$\begin{array}{cc}\text { тегорія } & \text {, їхня } \\
\text { функціон льн } & \text { зон }\end{array}$} & \multicolumn{10}{|c|}{ ісівницькі т інші з ходи } \\
\hline & 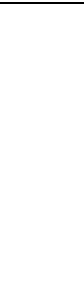 & 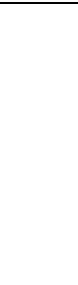 & 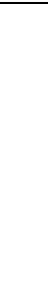 & 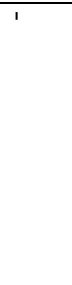 & 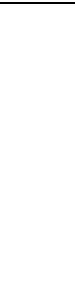 & 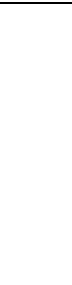 & 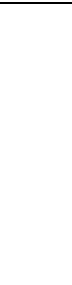 & 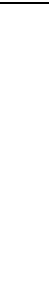 & 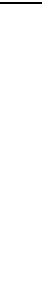 & 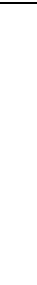 \\
\hline повідн зон & - & - & - & - & - & - & + & - & - & - \\
\hline $\begin{array}{l}\text { уферн зон , зон } \\
\text { регульов ної } \\
\text { рекре ції }\end{array}$ & - & + & + & + & + & - & + & + & + & - \\
\hline $\begin{array}{l}\text { он ст ціон рної } \\
\text { рекре ції }\end{array}$ & - & - & + & + & - & + & + & + & + & + \\
\hline $\begin{array}{l}\text { он нтропогенних } \\
\text { л ндш фтів, } \\
\text { господ рськ зон }\end{array}$ & - & + & + & + & + & + & + & + & + & + \\
\hline
\end{tabular}

дним із в жливих пок зників структури лісового фонду є його розподіл $3 \kappa$ тегоріями земель. ст ном н 1 січня 2010 р. 3 г льн площ лісового фонду ст новить 8536 г , з них 8048 г (94\%) прип д є н вкриту лісом площу, 174 г - н лісові культури ост нніх років, що не зімкнулися, тобто н землі, які використовують безпосередньо для вирощув ння н с джень (див. т бл. 2). озмір цих площ є головним кількісним пок зником р ціон льного використ ння земель лісового фонду. ешт земель лісового фонду н лежить до к тегорій невкритої лісом площі т нелісової площі.

о скл ду невкритої лісом площі входять г лявини, пустирі, нез ліснені лісосіки, рідколісся, зг рищ тощо. перев жній більшості це повноцінні землі, прид тні для вирощув ння високопродуктивних н с джень. ліснення н явної невкритої лісом площі - першочергове 3 вд ння лісового господ рств п рку.

скл ді нелісових земель - угіддя і площі особливого призн чення - сінож ті, води, дороги, просіки, к н ви, розс дники, с диби т інші землі. они є супутніми лісовій площі. о нелісових земель н леж ть т кож болот , піски, яри й крутосхили, які не використовують у лісовому господ рстві. жливе 3 вд ння лісового господ рств в п рку - проведення з ходів, спрямов них н поліпшення лісорослинних умов і переведення цих земель у лісову і вкриту лісом площу.

жливим пок зником лісового фонду п рку є видовий скл д лісів. ід деревної породи в тих чи інших умов х з лежить продуктивність н с джень, водоохоронно3 хисні функції, тов рний і сортиментний скл д деревини. идовий скл д лісів зн чною мірою визн ч є способи використ ння деревини. 
озподіл лісового фонду “ ерхньодністровські ескиди”

3 к тегоріями земель, г [2]

\begin{tabular}{|c|c|c|c|c|}
\hline \multirow[b]{2}{*}{ ок зНик } & \multicolumn{3}{|c|}{ ісництво } & \multirow[b]{2}{*}{ 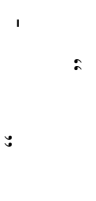 } \\
\hline & 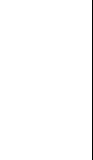 & 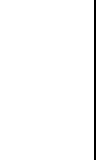 & 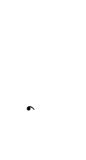 & \\
\hline г льн площ & 3768 & 2861 & 1907 & 8536 \\
\hline \multicolumn{5}{|c|}{ ісові землі } \\
\hline сього лісових земель & 3640 & 2796 & 1860 & 8296 \\
\hline криті лісовою рослинністю & 3538 & 2715 & 1795 & 8048 \\
\hline у тім числі лісові культури & 773 & 958 & 170 & 1901 \\
\hline езімкнуті лісові культури & 70 & 58 & 43 & 171 \\
\hline озс дники & 1 & 2 & - & 3 \\
\hline е вкриті лісовою рослинністю & 31 & 21 & 22 & 74 \\
\hline у тім числі зруби & 30 & 17 & 11 & 58 \\
\hline пустирі й прог лини & 1 & 4 & 11 & 16 \\
\hline \multicolumn{5}{|c|}{ елісові землі } \\
\hline сього нелісових земель & 128 & 65 & 47 & 240 \\
\hline гіддя & 72 & 36 & 14 & 120 \\
\hline у тім числі рілля & 1 & 2 & - & 3 \\
\hline сінож ті & 63 & 28 & 8 & 99 \\
\hline води & 8 & 4 & 6 & 18 \\
\hline лощі спецпризн чення & 27 & 14 & 18 & 59 \\
\hline у тім числі дороги, просіки & 22 & 14 & 16 & 52 \\
\hline с ди & 1 & - & - & 1 \\
\hline с диби & 4 & - & 2 & 6 \\
\hline лощі, які не використовуються & 5 & 17 & 15 & 61 \\
\hline у тім числі болот & 3 & 2 & - & 5 \\
\hline інші землі & 26 & 15 & 15 & 56 \\
\hline
\end{tabular}

приятливі грунтово-клім тичні умови, у яких розт шов ний п рк, зумовили різном нітний видовий скл д лісів, п нівними в якому були буково-ялицеві, ялицево-букові т смереково-ялицево-букові деревост ни [1]. ротягом грокультурного періоду він був зн чно спрощений т змінений ун слідок екологічно необгрунтов ного ведення лісового господ рств . ині н території п рку росте пон д 25 хвойних і листяних порід, які перев ж ють у н с дженнях. роте н йбільше поширені н території л ндш фтного п рку ялиця, сосн, смерек з групи шпилькових, бук, берез і вільх 3 листяних (див. рисунок). с дження з перев ж нням н зв них порід з йм ють пон д $93 \%$ вкритої лісом площі, решт - н с дження з перев ж нням інших порід (т бл. 3).

лизько $83 \%$ усіх лісів п рку ст новлять деревост ни з перев ж нням у скл ді н с джень хвойних порід (46\% - ялиця біл , 26,9\% - сосн звич йн , 9,2 \% - смерек ) і лише близько $15 \%$ - деревост ни з перев ж нням бук звич йного. кий скл д $€$ н слідком не 3 вжди екологічно обгрунтов ного ведення лісового господ рств в минулому. е стосується передусім зн чної ч стки сосни т смереки. творені поз 
меж ми їхнього природного ре лу культури виявилися біологічно нестійкими, їх пошкоджують коренев губк т опеньок, вони з зн ють руйнув ння від вітров лів і буреломів, тому підляг ють реконструкції.

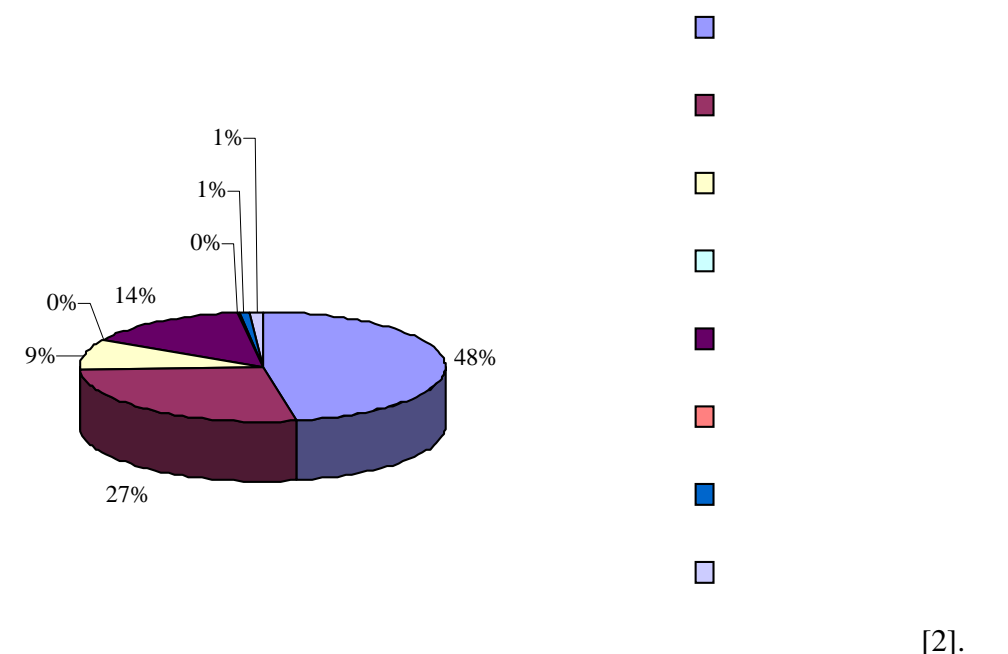

міни видового скл ду в ліс х п рку повинні відбув тися в н прямі збільшення площ н с джень цінних і продуктивних деревних порід ун слідок поступового неухильного скорочення площ похідних деревост нів. жливе зн чення м є відповідність створюв них лісових культур тип м лісорослинних умов. одноч с у п рку, що розміщений н невеликих бсолютних висот $\mathrm{x}$, досить сприятливі умови для вирощув ння дубових, букових т інших високопродуктивних н с джень. х треб пл нув ти у відповідних лісорослинних умов х н місці похідних гр бняків. вич йно зовсім вилуч ти гр 6 з н с джень недоцільно. отрібно лише обмежити його уч сть, щоб він посів н лежне місце в другому ярусі скл дних дубових і букових н с джень. ю породу вв ж ють н йв жливішим супутником дуб , вон сприяє підвищенню продуктивності дубових лісост нів.

ротягом ост нніх десятиріч н колишніх сільськогоспод рських землях п рку виникло пон д 77 г похідних вільшняків, 67 г березняків. е піонерні деревні породи, які поширюються спонт нно природним способом. скільки їхні деревост ни не м ють в гомого економічного зн чення, то їх потрібно поступово, з допомогою рубок переформув ння реконструюв ти. місці вторинних фітоценозів треб відтворюв ти корінні деревост ни, р нсформ ція похідних н с джень у корінні сприятиме підвищенню їхньої економічної в ртості, поліпшенню біологічної стійкості, отже, і підвищенню водоз хисної ролі.

дним 3 н йв жливіших пок зників лісового фонду в р зі розробки режиму охорони лісів є структур н с джень 3 віком. он д $є$ уявлення про площу лісів у меж х груп і кл сів віку т про з п си деревини, які можуть бути використ ні як нині, т к і в м йбутньому.

території л ндш фтного п рку в минулому вели інтенсивне лісове господ рство. ільшість деревост нів по кільк $\mathrm{p}$ зів пройдено н дмірними руб ннями. слідком цього ст л порушен віков структур в ліс х. лісовому фонді “ ерхньодніст- 
ровські ескиди" порівняно невелик площ молодняків (16\%), б г то середньовікових лісів (72\%), незн чн ч стк достиг ючих (9\%), стиглих (2\%) і м йже нем перестійних деревост нів. кий розподіл лісів 3 віком д є підст ви стверджув ти, що в н ступні дв десятиріччя, доки основн ч стин н с джень середнього віку не почне переходити в групу стиглих, у них треб проводити лише прохідні руб ння. огляду н нез довільний ст н стиглих н с джень потрібно н кл сти тимч совий мор торій н проведення в них суцільних руб нь. ля з доволення потреб господ рств в деревині можн рекомендув ти у стиглих ліс х групово-вибіркові т добровільно-вибіркові рубки. е д сть змогу з безпечити іхнє природне відновлення т зберегти з хисну функцію.

блиця 3 идовий скл д т віков структур лісів “ ерхньодністровські ескиди” [2]

\begin{tabular}{|c|c|c|c|c|c|c|c|c|c|c|c|}
\hline \multirow[b]{3}{*}{$\begin{array}{c}\text { оловн } \\
\text { лісоутворюв льн } \\
\text { пород }\end{array}$} & \multirow{3}{*}{ 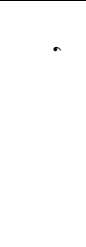 } & \multicolumn{10}{|c|}{ у тім числі групи віку } \\
\hline & & \multicolumn{2}{|c|}{ молодняки } & \multicolumn{2}{|c|}{ середньовікові } & \multicolumn{2}{|c|}{ достиг ючі } & \multicolumn{2}{|c|}{ стиглі } & \multicolumn{2}{|c|}{ перестійні } \\
\hline & & 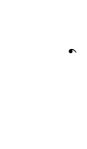 & $\%$ & 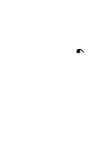 & $\%$ & 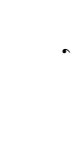 & $\%$ & 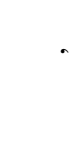 & $\%$ & 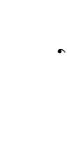 & $\%$ \\
\hline \multicolumn{12}{|c|}{ пилькові } \\
\hline лиця біл & 3400 & 1074 & 31,59 & 2011 & 59,15 & 268 & 7,88 & 47 & 1,38 & - & - \\
\hline ОсН ЗВИЧ ЙН & 1957 & 19 & 0,97 & 1830 & 93,51 & 108 & 5,52 & - & - & - & - \\
\hline 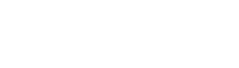 & 673 & 47 & 6,98 & 608 & 90,34 & 18 & 2,67 & - & - & - & - \\
\hline $\begin{array}{c}\text { одрин } \\
\text { європейськ }\end{array}$ & 17 & - & - & - & - & 10 & 58,82 & - & - & 7 & 41,18 \\
\hline $30 \mathrm{M}$ & 6047 & 1140 & 18,85 & 4449 & 73,57 & 404 & 6,68 & 47 & 0,78 & 7 & 0,12 \\
\hline \multicolumn{12}{|c|}{ вердолистяні } \\
\hline уб червоний & 10 & 5 & 50,00 & 5 & 50,00 & - & - & - & - & - & - \\
\hline ук лісовий & 1042 & 15 & 1,44 & 749 & 71,88 & 200 & 19,19 & 78 & 7,49 & - & - \\
\hline p б звич Йний & 10 & - & - & 10 & 100,00 & - & - & - & - & - & - \\
\hline сен звич йний & 4 & - & - & 4 & 100,00 & - & - & - & - & - & - \\
\hline Bip & 15 & 2 & 13,33 & 13 & 86,67 & - & - & - & - & - & - \\
\hline $30 \mathrm{M}$ & 1081 & 22 & 2,03 & 781 & 72,25 & 200 & 18,50 & 78 & 7,22 & - & - \\
\hline \multicolumn{12}{|c|}{ 'яколистяні } \\
\hline ерез повисл & 67 & - & - & 11 & 16,42 & 56 & 83,58 & - & - & - & - \\
\hline ільх сір & 74 & 7 & 9,46 & 1 & 1,35 & 14 & 18,92 & 51 & 68,92 & 1 & 1,35 \\
\hline ільх чорн & 3 & 3 & - & - & - & - & - & - & - & - & - \\
\hline $30 \mathrm{M}$ & 144 & 11 & 4,86 & 12 & 8,33 & 70 & 48,61 & 51 & 35,42 & 1 & 0,69 \\
\hline сього & 7272 & 1172 & 16,12 & 5242 & 72,08 & 674 & 9,27 & 176 & 2,42 & 8 & 0,11 \\
\hline
\end{tabular}

перспективі структур лісів п рку з віком м є поступово поліпшув тися, що зумовить збільшення середнього віку лісів. евні кількісні т якісні зміни в лісовому фонді з умови проведення лісогоспод рських з ходів д дуть змогу збільшити обсяг лісокористув ння поряд з посиленням водоохоронно-з хисних функцій лісу. крит лісом площ збільшиться в зв'язку з повнішим використ нням земель лісового фонду 
і з лісненням неприд тних для сільського господ рств земель, збільшиться середній приріст лісів, з п с деревини, поліпш ться видовий скл д і якість лісост нів.

ропонов ні види руб нь т інших лісогоспод рських з ходів треб узгоджув ти 3 функціон льним зонув нням території п рку. ж ль, сьогодні функціон льне зонув ння в “ ерхньодністровські ескиди” поки що не розроблене.

тже, у ході природоохоронного впорядкув ння регіон льних л ндш фтних п рків і обгрунтув ння екологічних з с д їхнього упр вління т розвитку потрібно приділяти н лежну ув гу оптиміз ції структури лісового фонду. “ ерхньодністровські ескиди" створено 1997 р. н 8536 г земель лісового фонду т рос мбірського держлісгоспу без вилучення. лісовому фонді л ндш фтного п рку н гірських хребт х - гурському (730 м н. р. м.), орівському (762 м н. р. м.), гуроімнянському (1 022 м н. р. м.) збереглися природні букові т ялицево-букові ліси. ротягом ст. в ліс х п рку вели інтенсивне лісове господ рство. н слідок цього структур лісового фонду з зн л нтропогенних змін. ліс х п рку високий відсоток вторинних лісів з перев ж нням у деревост н х сосни т смереки. і ліси необхідно реконструюв ти відповідно до типів лісорослинних умов. кож н території змінен віков структур деревост нів. кі ліси не зд тні повною мірою виконув ти еколого-ст біліз ційну роль.

оби зберегти різном ніття лісових видів, потрібно поліпшув ти вікову й ценотичну структуру тр нсформов них деревост нів у регіон льних л ндш фтних п рк х.

1. онцепту льні з с ди ст лого розвитку гірського регіону / . . олубець, . . н тів, . . озловський [т ін.]. - ьвів : оллі, 2007. - 288 с.

2. тері ли ьвівської лісовпорядкув льної експедиції “крдержліспроект” по “ т рос мбірське 32010 p.

3. етодичні рекоменд ції щодо режиму збереження лісових екосистем н територіях природно-з повідного фонду кр їни різних к тегорій / . . теценко, . . ременко, . . рфенюк. - . : ид-во кр. фітосоціол. центру, 2003. - 56 с.

4. опович. . повідне лісозн вство: [н вч. посіб.] / . . опович, . . орінько, . . стименко. - ернопіль : вч. Книг - огд н, 2009. - 384 с.

5. еліш . . ндш фтні особливості об'єктів природно-з повідного фонду ерхньодністерських ескид / . . еліш // озвиток 3 повідної спр ви в кр їні і формув ння п н'європейської екологічної мережі : м тері ли міжн р. н ук.-пр кт. конф. ( хів, 11-13 листоп д 2008 р.). - хів, 2008. - . 398-403.

6. озміщення л ндш фтних п рків ольщі : [ лектронний ресурс]. - ежим доступу : http://www.ekoportal.gov.pl/opencms/ekoportal/Ekoturystyka/Parki_Krajobrazowe.

7. ро роект орг ніз ції території регіон льного л ндш фтного п рку, охорони, відтворення т рекре ційного використ ння його природних комплексів т об'єктів.

к 3 іністерств екології і природних ресурсів кр їни від 6 липня 2005 р. № 245 : [ лектронний ресурс]. - ежим доступу: http://zakon4.rada.gov.ua/laws/show/z0832-05.

8. ро егіон льну прогр му з безпечення діяльності регіон льних л ндш фтних п рків обл сті н 2011-2013 роки. ішення № 102 від 05 квітня 2011 року : 
[ лектронний ресурс]. - ежим доступу: http://www.oblrada.lviv.ua/index.php?option $=$ com_joomdoc\&task=doc_details\&gid.

m ття: н дійшл до ред кцї̈ 30.11.2012

доопр иьов н 01.04 .2013

прийнят до друку 16.05.2013

\title{
STRUCTURE OF FORESTS FUND OF REGIONAL LANDSCAPE PARK “UPPER-DNIESTER BESKIDS”, IT ANTHROPOGENIC TRANSFORMATION AND WAYS TO OPTIMIZATION
}

\author{
Pavlo Telish \\ Ivan Franko National University of Lviv, \\ P. Doroshenko St., 41, UA - 79000 Lviv, Ukraine
}

The present structure of the forest fund of regional park "Upper-Dniester Beskids" for the purpose of selecting of the optimal mode use of forest resources was investigated. Intensive forest management during the twentieth century led to adverse changes in the structure of the forest fund of landscape park. Distribution of forest of park by protection category and land category was analyzed. Species composition and age structure of forests of regional landscape parks were clarified. The degree of anthropogenic transformation of forest of park was identified. Optimization measures which should be carried out on the basis of functional zoning of the regional landscape park "Upper-Dniester Beskids" were proposed to improve the modern structure of the forest fund.

Key words: regional landscape park "Upper-Dniester Beskids", structure of forest fund, anthropogenic transformation, ways to optimization.

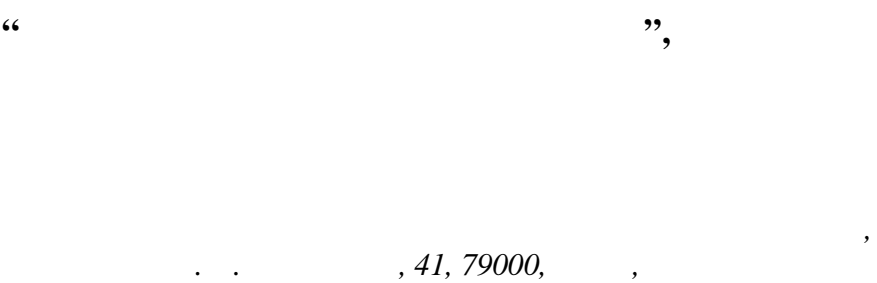

сследов но современную структуру лесного фонд регион льного л ндш фтного п рк “ ерхнеднестровские ескиды” с целью последующего выбор оптим льного режим использов ния лесных ресурсов. нтенсивное лесопользов ние в в. привело к изменениям в структуре лесного фонд л ндш фтного п рк . ро н лизиров но р спределение лесов п рк по к тегориям 3 щитности и к тегориям земель, выяснено видовой сост в и возр стную структуру лесов регион льного л ндш фтного п рк . пределено степень нтропогенной тр нсформ ции лесов п рк . ля улучшения современной структуры лесного фонд предложено оптимиз ционные мероприятия, которые следует проводить с учетом функцион льного зониров ния территории регион льного л ндш фтного п рк “ ерхнеднестровские ескиды”.

лючевые слов : регион льный л ндш фтный п рк “ ерхнеднестровские ескиды”, структуp лесного фонд, нтропогенн я тр нсформ ция, способы улучшения. 